\title{
INVESTIGATION OF THE MICROBIAL-INDUCED CORROSION POTENTIAL OF SOILS IN SOUTHERN IJAW LGA IN NIGER DELTA, NIGERIA
}

\author{
Y. T. PUYATE AND A. RIM-RUKEH
}

(Received 1 October 2007; Revision Accepted 15 May 2008)

\begin{abstract}
Investigation of sulphate-reducing bacteria induced corrosion potential of soils along 18-inch 45km Tebidaba/Brass underground oil pipeline in Southern ljaw LGA of Bayelsa State, Nigeria, is carried out experimentally. The analysis involves determination of some physico-chemical parameters of soils in the pipeline route, and testing corrosion products formed on the surfaces of X60 steel coupon buried in the soils for one year. It is shown that the soils are clayey in nature and highly corrosive with high population of sulphate-reducing bacteria $\left(10^{4}-10^{6} \mathrm{cfu} / \mathrm{g}\right)$. The ranges of other measured properties of the soils $(\mathrm{pH}(4.8-5.2)$, temperature $(17$ $\left.-21^{\circ} \mathrm{C}\right)$, water content $(79-89 \%)$, organic matter $(10.7-15.6 \%$ dry wt), redox potential $(-79$ to $-95 \mathrm{mV})$, sulphate $(0.8-$ $13.6 \mathrm{mg} / \mathrm{l})$ ) favour growth of sulphate-reducing bacteria. Black deposits on the surfaces of the buried coupons are iron sulphide resulting from attack on the metal by sulphate-reducing bacteria in the soils.
\end{abstract}

KEY WORDS: sulphate-reducing bacteria; soil; corrosion; pipeline; crude oil

\section{INTRODUCTION}

Sulphate-reducing bacteria (SRB) are a group of anaerobic heterotrophs that use sulphate or occasionally sulphur to accept electrons released by oxidation of nutrients and produces sulphide as by-product. The sulphate-reducing bacteria group is the most studied in relation to corrosion and has been identified in a number of pitting and fatigue corrosion processes (Postgate, 1979; Sanders, 1983; Rosser and Hamilton, 1983; Pryfogle, 2002). There are several theories on the mechanism of SRB induced corrosion (Neville and Hodgikiess, 2000; Iverson, 1980; King and Miller, 1971; Starkey and Wight, 1983; Geesay et al., 2002). It is well known that sulphate-reducing bacteria have several species with different characteristics in terms of enzyme systems, organic carbon and sulphur utilization, environmental tolerance, etc. Examples of common species of sulphate-reducing bacteria include Desulfovibrio gigas, Desulfovibrio vulgaris, Desulfotomaculum acetoxidans, and Desulfobacter postgatei (Schlegel, 1993).

SRB have been implicated in a number of anaerobic corrosion problems in the oil industry (Starkey and Wight, 1983; Levlin, 1992). This study is motivated by repeated failure due to corrosion of 18 -inch $45 \mathrm{~km}$ Tebidaba/Brass underground pipeline carrying crude oil from Tebidaba Flow Station to Brass Oil Terminal. Within two years $(2002-2004), 13$ cases of corrosion failure of the pipeline have been reported (NAOC, 2005). When studying corrosion failure, Videla (1996) and Stein (1993) suggested laboratory examination of the environment where a corroded metal is located and analysis of deposits formed on the corroded material. This paper investigates SRB induced corrosion potential of soils along Tebidaba/Brass underground oil pipeline in the Niger Delta area of Nigeria through measurement of some physicochemical parameters of the soils along the pipeline route and analysis of corrosion products formed on the surfaces of X60 steel coupons buried in the soils for one year. X60 steel is used in the present study because it is the material for construction of most pipes used in the oil sector in Nigeria, including the Tebidaba/Brass underground oil pipeline.

\section{MATERIALS AND METHODS}

\subsection{Study Area}

The 18-inch $45 \mathrm{~km}$ Tebidaba/Brass pipeline is located in Southern ljaw Local Government Area of Bayelsa State, Nigeria. Rainfall in the area averages $2500 \mathrm{~mm}$ annually, and the rainfall pattern shows two distinct seasons: the rainy season (April to October) and a relatively short dry season (November to March). Previous meteorological study of the area (Gobo, 1998) reveals average atmospheric temperature of $25.50^{\circ} \mathrm{C}$ in the rainy season and $30^{\circ} \mathrm{C}$ in the dry season. The daily average relative humidity is about $55.5 \%$ in the dry season and $96 \%$ in the rainy season. The area is a vast flood plain built by accumulation of sedimentary deposits washed down the Niger and Benue rivers. The area is criss-crossed with numerous rivers, streams, tributaries, creeks, and creeklets.

\subsection{Preparation of $\mathrm{X} 60$ steel coupons used in the study}

Sheets of X60 steel were obtained from Tricorr (Nig) Ltd., Port Harcourt, Nigeria, and cold-cut to the dimensions $10 \mathrm{~cm} \times 5 \mathrm{~cm} \times 0.5 \mathrm{~cm}$. The cold-cut technique was used to avoid probable effect of heat-affected zone (HAZ) on corrosion, and to maintain the integrity of the steel. The coupons were surface-finished by scrubbing with 80 -grit sandpapers, sterilized by dipping in pure ethanol, and degreased by washing them in acetone. The exposed surface area of each coupon is $115 \mathrm{~cm}^{2}$ and is calculated as $2(L w+L h+h w)$,

where $L=10 \mathrm{~cm}$ is the length of each rectangular coupon, $w=5 \mathrm{~cm}$ is the width, and $h=0.5 \mathrm{~cm}$ is the thickness (or height) of the coupon. Nine (9) pieces of X60 steel coupons were prepared for the study, and the mass of each coupon ranges from $19.95 \mathrm{~g}$ to $20.03 \mathrm{~g}$. X60 steel presents a microstructure of ferrite and Table 1 shows the elemental composition of the metal.

Y. T. Puyate, Department of Chemical Engineering, Rivers State University of Science and Technology, Port Harcourt P. M. B. 5080, Port Harcourt, Nigeria.

A. Rim-Rukeh, Department of Integrated Science, College of Education, P. M. B. 2090, Agbor, Delta State, Nigeria. 
Table 1: Elemental composition of $X 60$ steel (Benmoussat and Hadjel, 2005).

\begin{tabular}{|c|l|l|c|c|c|c|c|c|c|c|}
\hline $\begin{array}{c}\mathrm{C} \\
(\%)\end{array}$ & $\begin{array}{l}\mathrm{Mn} \\
(\%)\end{array}$ & $\begin{array}{l}\mathrm{P} \\
(\%)\end{array}$ & $\begin{array}{c}\mathrm{S} \\
(\%)\end{array}$ & $\begin{array}{c}\mathrm{Cr} \\
(\%)\end{array}$ & $\begin{array}{c}\mathrm{Ni} \\
(\%)\end{array}$ & $\begin{array}{c}\mathrm{Mo} \\
(\%)\end{array}$ & $\begin{array}{c}\mathrm{V} \\
(\%)\end{array}$ & $\begin{array}{c}\mathrm{Cu} \\
(\%)\end{array}$ & $\begin{array}{c}\mathrm{Al} \\
(\%)\end{array}$ & $\mathrm{Fe}$ \\
\hline 0.199 & 1.59 & 0.016 & 0.018 & 0.015 & 0.007 & 0.008 & 0.004 & 0.024 & 0.024 & 98.095 \\
\hline
\end{tabular}

\subsection{Collection of soil samples}

Nine (9) soil sampling points were established along the 18inch $45 \mathrm{~km}$ Tebidaba/Brass pipeline at a distance of $5 \mathrm{~km}$ from one another, and X60 steel coupon was buried at each sampling site at a depth of $1.0-1.1 \mathrm{~m}$ for one year (November 2005 - October 2006). The depth of the coupons is based on the average depth of about $1 \mathrm{~m}$ of underground oil pipeline below the earth's surface. In the $12^{\text {th }}$ month (i.e. October 2006), all the buried coupons were retrieved from the various sites on the same day and taken immediately to the laboratory for analysis. Soil samples were also collected for analysis from each sampling site at a depth of about $1 \mathrm{~m}$ on the same day the coupons were buried. Since the study area has two distinct seasons (rainy and dry seasons), it is expected that the different meteorological characteristics of the two seasons would have severe effects on the physico-chemical properties of the soil. However, the properties of the soils are not expected to vary significantly with the seasons because the study area is swampy and water-logged throughout the year. For this reason, soil samples were not taken to account for the two seasons. Samples for physico-chemical and biological analyses were collected in polyethylene bags and McCartney bottles respectively.

\subsection{Experimental methods}

\section{Soil samples}

Soil samples were analyzed for $\mathrm{pH}$, temperature, redox potential, organic matter, water content, sulphate, and sulphate-reducing bacteria count. Temperature and $\mathrm{pH}$ of the soil samples were determined in situ between 11am and 12noon using a multi-parameter water quality monitor (Model 6000 UPG) because these properties vary with time. Redox potential (Eh) of the soil samples was determined using an Orion multimeter (Model 1260) combined with platinum electrode immersed directly in soil sample saturated with water. Organic matter in the soils was estimated by burning $5 \mathrm{~g}$ of the dry soil sample in an oven at $500^{\circ} \mathrm{C}$ for $1 \mathrm{hr}$ and calculating the mass-loss. The water content of soils was determined using mass - loss technique, by weighing $5 \mathrm{~g}$ of the soil sample accurately into a crucible and drying in an oven at a temperature of $105^{\circ} \mathrm{C}$ for a day, cooled in a dessicator, and weighed; the amount of moisture was determined by mass difference and expressed as a percentage of the initial mass of the soil sample. Sulphate concentration was determined turbimetrically using potassium sulphate standard (Atlas and Parks, 1993). The type of soil in the pipeline route was identified using the following characteristics: (i) ability of water to penetrate the soil, (ii) the ease with which the soil is washed off the excavating equipment (shovel), and (iii) the consistency of the soil when manipulated in one's hand. The number of sulphate-reducing bacteria in the soil samples was determined by the most Most Probable Number (MPN) technique (Cochran, 1950). All methods of analysis described above are consistent with DPR (2002) and AWWA (2001) standards.

\section{Corrosion products on buried coupons}

A visual check was performed on all the buried X60 steel coupons retrieved from the soils. After cleaning dirt from the surfaces of the coupons, no visible pits were found on the coupon surfaces. It is worthy of note, however, that visual check does not rule out the possibility of localised (pitting) corrosion and does not even ascertain complete removal of the corrosion products. All the same, the coupons retrieved from the soils were less shiny because of red coating and black deposits on their surfaces. The red coating and black deposits were scrapped off the coupon surfaces using a surgical spatula and then reacted with $5 \mathrm{ml}$ of $0.2 \mathrm{M}$ hydrochloric acid to produce a gas with the smell of rotten egg. Note that the black deposits appear as dotted spots in the red coating, so it is impossible to scrap these materials separately from the metal surfaces. Hence, the black deposits and red coating were scrapped off together from the metal surfaces.

\section{RESULTS AND DISCUSSION}

\subsection{Soil samples}

Table 2 shows results of the analyses carried out on the soil samples collected from the sampling points along the route of the Tebidaba/Brass pipeline. The $\mathrm{pH}$ of the soil samples varies from 4.8 to 5.2 (indicating that the soils are acidic in nature), and lies with the limits $(4.5$ - 7.3) for sulphate-reducing bacteria (Engvall, 1986). Bradford (1993) indicated that acidic environment with $\mathrm{pH}<6$ are more corrosive than $\mathrm{pH}$ from 6 to 8 or alkaline $\mathrm{pH}>8$, though it is argued by Harris (1960) that $\mathrm{pH}$ within the range $5-9$ has no effect on corrosion. The acidity of the soils may have resulted from humic acid (HA) formed from decomposing organic matter. It has also been observed that soils can be acidic due to leaching of basic cations $\left(\mathrm{Ca}^{2+}, \mathrm{Mg}^{2+}, \mathrm{Na}^{+}\right.$, and $\mathrm{K}^{+}$) by rainwater (Benmoussat and Hadjel, 2005).

Table 2: Measured parameters of soil samples along Tebidaba/Brass pipeline.

\begin{tabular}{|l|l|l|l|l|l|l|l|l|}
\hline \multirow{2}{*}{$\begin{array}{l}\text { Sampling } \\
\text { site }\end{array}$} & $\mathrm{pH}$ & $\begin{array}{l}\text { Temp. } \\
\left({ }^{\circ} \mathrm{C}\right)\end{array}$ & $\begin{array}{l}\text { Soil } \\
\text { type }\end{array}$ & $\begin{array}{l}\text { Water } \\
\text { content } \\
(\%)\end{array}$ & $\begin{array}{l}\text { Organic } \\
\text { matter } \\
(\% \text { dry wt })\end{array}$ & $\begin{array}{l}\text { Redox } \\
\text { potential } \\
(\mathrm{mV})\end{array}$ & $\begin{array}{l}\mathrm{SO}_{4}{ }^{2-} \\
(\mu \mathrm{g} / \mathrm{g})\end{array}$ & $\begin{array}{l}\text { SRB } \\
\text { count } \\
(\mathrm{cfu} / \mathrm{g})\end{array}$ \\
\hline 1 & 5.1 & 17 & Clay & 83 & 13.5 & -80 & 0.19 & $10^{4}$ \\
\hline 2 & 4.9 & 19 & Clay & 79 & 10.7 & -95 & 0.21 & $10^{5}$ \\
\hline 3 & 5.2 & 18 & Clay & 83 & 11.2 & -87 & 0.26 & $10^{4}$ \\
\hline 4 & 4.8 & 20 & Clay & 84 & 15.6 & -79 & 0.32 & $10^{5}$ \\
\hline 5 & 5.2 & 21 & Clay & 89 & 11.9 & -82 & 0.33 & $10^{5}$ \\
\hline 6 & 5.1 & 20 & Clay & 79 & 12.8 & -79 & 0.29 & $10^{4}$ \\
\hline 7 & 4.9 & 18 & Clay & 80 & 14.6 & -82 & 0.37 & $10^{6}$ \\
\hline 8 & 5.0 & 18 & Clay & 83 & 13.7 & -81 & 0.35 & $10^{4}$ \\
\hline 9 & 5.1 & 19 & Clay & 87 & 15.1 & -83 & 0.27 & $10^{5}$ \\
\hline
\end{tabular}


Temperature is an important parameter that can affect the interaction between the metal and the soil (Bradford, 1993). Directly or indirectly, temperature affects all the factors that govern microbial growth. For example, the growth rate of $E$. Coli bacteria was found to be slow at temperature below $20^{\circ} \mathrm{C}$ and faster at temperature ranging from $25^{\circ} \mathrm{C}$ to $40^{\circ} \mathrm{C}$ (Booth, 1971). The optimal temperature for bacterial growth is between $25^{\circ} \mathrm{C}$ and $30^{\circ} \mathrm{C}$, although they can grow within wider temperature range $\left(10^{\circ} \mathrm{C}-37^{\circ} \mathrm{C}\right)$. The temperature of the soil samples lies in a range from $17^{\circ} \mathrm{C}$ to $21^{\circ} \mathrm{C}$, which favours bacterial growth and is consistent with reported values for such environment (Rahaman, 1976). The type of soil at the sampling sites at a depth of about $1 \mathrm{~m}$ is clayey in nature, and is consistent with reported soil characteristics of the Niger Delta (Rahaman, 1976; Omorodion, 1988). The soil was identified to be clay because it retains water, difficult to be washed off the excavating equipment, and is consistent when manipulated in one's hand.

The water content of the soil samples ranges from $79 \%$ to $89 \%$. The high water content in all soil samples may be attributed to ground water level, precipitation, and permeability of the soil. It has been found that pipeline ditch is a favourable environment for bacteria because trench backfill does not consolidate to a great degree as an undisturbed soil even after many years (Harris, 1960); this permits easy penetration of water throughout the backfill. Using the AWWA (2001) numerical scale for soil corrosivity, the water content in the soil was assigned a value of 3 on a scale of 4 (for this parameter) which indicates that the soil is moist. A key feature that initiates and promotes biocorrosion is water or aqueous medium which is the main requirement for microbial life and corrosion to occur (EPA, 1992). Supply of organic matter is important for sulphate-reducing bacteria as these bacteria usually require organic carbon as electron donor. Organic carbon is utilized by bacteria for the production of new cells (assimilation) and as an energy source (dissimilation). The investigated soil samples are rich in organic matter (10.7-15.6 $\%$ dry wt.).

Redox potential (Eh), that is, the oxidizing or reducing state of an environment is related to the amount of oxygen in the environment and can be used to determine the class of bacteria that is likely to grow in an environment. Eh has been used to determine the suitability of a culture medium for anaerobic or aerobic bacterial growth (Booth, 1971). It has also been used to assess corrosion hazard due to SRB in soils and to predict corrosion behaviour of aluminium nickel and zinc in cultures of different bacteria (Pritchard, 2002). The broad spectrum of redox potential under which microbial life can be observed ranges from $-450 \mathrm{mV}$ to $+450 \mathrm{mV}$, where the negative side of the spectrum favours methanogenic bacteria and the positive side correspond to iron bacteria (Newman et al., 1991). A negative redox potential indicates a corrosive environment (Booth, 1971), and SRB are only able to grow in highly reduced conditions with redox potential in range from $-100 \mathrm{mV}$ to $-80 \mathrm{mV}$ (Newman et al, 1991). Although SRB are generally anaerobic (obligate anaerobes), some species of SRB tolerate oxygen and also grow in low-oxygen concentration environment (Schlegel, 1993). The redox potentials of the soil samples $(-79 \mathrm{mV}$ to $-95 \mathrm{mV})$ may be seen to be consistent with the above range for SRB growth. A low redox potential indicates that oxygen content of the soil is low, which is ideal for proliferation of SRB. Using AWWA (2001) numerical scale for soil corrosivity, the redox potential of the soil was assigned 5 points on a scale of 5 (for this parameter) indicating that the soil is highly corrosive.

Sulphate is used by microorganisms to facilitate metabolic processes. The presence of sulphate or its compounds helps to stimulate bacterial growth especially SRB. Therefore, the amount of sulphate in the soil is important, and generally high sulphate concentrations give high reduction rates. The soil samples contain relatively high sulphate concentrations $(0.19-0.37 \mu \mathrm{g} / \mathrm{g})$. Although SRB are of very small size, their great number can produce a respectable mass of material. SRB level in the soil ranges from $10^{4} \mathrm{cfu} / \mathrm{g}$ to $10^{6} \mathrm{cfu} / \mathrm{g}$. Videla (1996) and Costello (1969) observed that SRB level of $10^{4} \mathrm{cfu} / \mathrm{g}$ and above is a clear indication of possible corrosion problem, while a relative population of $10^{6} \mathrm{cfu} / \mathrm{g}$ is a concern of potential corrosion problem in an environment (Costello, 1969). The high population of SRB in the soil samples $\left(10^{4}-10^{6} \mathrm{cfu} / \mathrm{g}\right)$ also indicates the availability of nutrients in the region.

\subsection{Corrosion products on buried coupons}

When $\mathrm{X} 60$ steel (with iron as the major component) is exposed to anaerobic and moist environment, it gradually rusts due to the formation of hydrated iron (III) oxide $\left(\mathrm{Fe}_{2} \mathrm{O}_{3} \cdot x \mathrm{H}_{2} \mathrm{O}\right)$ in the form (Ababio, 2004)

$$
4 \mathrm{Fe}+3 \mathrm{O}_{2}+2 x \mathrm{H}_{2} \mathrm{O} \rightarrow 2 \mathrm{Fe}_{2} \mathrm{O}_{3} \cdot x \mathrm{H}_{2} \mathrm{O}
$$

Under anaerobic condition as in soil medium, the iron in the buried X60 steel coupons may be partially oxidized and exists as iron (II) oxide. Iron bacteria have the ability to oxidize iron (II) oxide to iron (III) oxide, during which, iron hydroxide is deposited on the metal surface (Videla, 1996). Since iron bacteria exist in an environment with positive redox potential (Newman et al, 1991), the contribution of this group of bacteria to the corrosion of coupons buried in soils with negative redox potential is minimal. Therefore, the red coating on the surfaces of the buried coupons may be rust and not the result of activities of iron bacteria in the soils. The black deposits on the buried coupons are iron sulphide resulting from attack on the metal by SRB in the soils (Lee et al., 1995). The iron sulphide reacts with hydrochloric acid to produce hydrogen sulphide gas with the smell of rotten egg. The evolution of hydrogen sulphide gas indicates the participation of SRB in the microbial corrosion of the Tebidaba/Brass pipeline ((Jones, 1988).

\subsection{Corrosion rates of buried coupons}

The nine (9) X60 steel coupons were buried on the same day in November 2005, and retrieved on the same day in October 2006. The corrosion rate of each coupon is calculated using the mass-loss technique (Bradford, 1993; Rim-Rukeh and Puyate, 2007) as

$$
\text { Corrosion rate (mpy) }=\frac{\Delta M \times 3.45 \times 10^{6}}{A \rho t}
$$

where $\Delta M$ is the mass loss $(\mathrm{g})$ of the coupon, $A$ is the total exposed surface area of the coupon $\left(\mathrm{cm}^{2}\right), \rho$ is the density of the coupon $\left(\mathrm{g} / \mathrm{cm}^{3}\right)$, and $t$ is time (hours). Table 3 shows the corrosion rates of the various coupons for a period of one year.

Table 3: Corrosion rates of buried coupons for a period of one year

\begin{tabular}{|l|l|l|}
\hline Sampling site & Mass-loss $(\mathrm{g})$ & $\begin{array}{l}\text { Corrosion rate } \\
(\mathrm{mpy})\end{array}$ \\
\hline 1 & 0.85 & 3.53 \\
\hline 2 & 0.89 & 3.72 \\
\hline 3 & 0.94 & 3.91 \\
\hline 4 & 0.97 & 4.05 \\
\hline 5 & 0.99 & 4.13 \\
\hline 6 & 0.88 & 3.68 \\
\hline 7 & 0.96 & 4.01 \\
\hline 8 & 0.90 & 3.76 \\
\hline 9 & 0.91 & 3.80 \\
\hline
\end{tabular}

Thus, the corrosion rates of the various coupons range from 3.55 to $4.13 \mathrm{mpy}$, indicating that the soils along the pipeline route have similar characteristics. The differences in the 
corrosion rates of the coupons may be linked to the sulphate concentration in the soils at the different sampling sites and the relative concentrations of SRB (see Table 2). Since the soils have been identified through the range of redox potential to be highly corrosive, the range of corrosion rates in Table 2 corresponds to a highly corrosive environment.

\section{CONCLUSION}

Sulphate-reducing bacteria induced corrosion potential of soils along 18-inch $45 \mathrm{~km}$ Tebidaba/Brass underground oil pipeline has been investigated. It is shown that the soils along the pipeline route are highly corrosive with high population of sulphate-reducing bacteria. The ranges of measured temperature, $\mathrm{pH}$, water content, organic matter, sulphate, and redox potential of the soils favour growth of sulphate-reducing bacteria. The black deposits formed on the surfaces of the buried coupons is iron sulphide resulting from attack on the metal by sulphate-reducing bacteria in the soils, while the red coating on the buried coupon surfaces may be rust. Thus, the repeated failure due to corrosion of the Tebidaba/Brass oil pipeline is caused partly by sulphate-reducing bacteria in the soil.

\section{REFERENCES}

Ababio, O. Y., 2004. New School Chemistry, $3^{\text {rd }}$ ed., African First Publishers Ltd., Onitsha, Nigeria, 448-449.

Atlas, R. M. and Parks, L. C., 1993. Handbook of Microbiological Media, Florida: Boca Raton, 501 502.

AWWA, 2001. American Water Works Association: Standards for Determining Corrosivity of soils, AWWA specification C-105.

Benmoussat, A. and Hadjel, M., 2005. Corrosion behaviour of low carbon line pipe steel in soil environment, The Journal of Corrosion Science and Engineering, 6(9): 1178-1183.

Booth, G. H., 1971. Microbiological Corrosion, London: Mills and Boon Ltd.

Bradford, S. A., 1993. Corrosion Controls, New York: Van Nostrand Reinhold.

Cochran, W. G., 1950. Estimation of bacterial densities by means of the most probable number method, Biometrics, 6: 105-116.

Costello, J. A., 1969. The corrosion of metals by microorganisms: A literature survey, International Biodeterioration Bulletin, 5: 101-106.

DPR (2002). Department of Petroleum Resources: Environmental Guidelines and Standards for Petroleum Industry in Nigeria.

Engvall, A. G., 1986. Corrosion of soil related to the presence of sulphate-reducing bacteria, Biodeterioration, 7: 813-822.

EPA, 1992. Environmental Protection Agency: Seminar publication on the control of biofilm growth in drinking water distribution systems, EPA/625/R-92/001.

Geesay, M. R., Clayton, C. R. and Gillow, J. B., 2002. Influence of sulphate-reducing bacteria on the passive film formed on austentic stainless steel AISI 304, Corrosion 95/ Paper No. 214, NACE, Houston, Texas.
Gobo, A. E., 1998. Meteorology and Man's Environment, Ibadan: African-Link Books, 101-127.

Harris, J. O., 1960. Soil microorganisms in relation to cathodically protected pipe, Corrosion, 16: 441-448.

Iverson, W. P., 1980. Microbial corrosion in metals, Advances in Applied Microbiology, 32: 1 - 4.

Jones, L. W., 1988. Corrosion and Water Technology for Petroleum Producers, Tulso: Oil and Gas Consultants International Inc.

King, R. A. and Miller, J. D. A., 1971. Corrosion by sulphatereducing bacteria, Nature, 233: 491-492.

Lee, W., Lewandowski, Z., Nielsen, P. H. and Hamilton, W. A. 1995. Role of sulphate-reducing bacteria in corrosion of mild steel: A review, Biofouling, 8(3): 165-169.

Levlin, E., 1992. Corrosion of Water Pipe Systems due to Acidification of soil and Groundwater, M.Sc Thesis, Department of Applied Electro-Chemistry and Corrosion Science, Royal Institute of Technology, Stockholm.

NAOC, 2005. Nigerian Agip Oil Company: Oil Spill Statistics from 1994-2005.

Neville, A. and Hodgikiess, T. 2000. Corrosion of stainless steels in marine conditions containing sulphatereducing bacteria, British Corrosion Journal, 35(1): 60-69.

Newman, R. C., Webester, B. J. and Kelly, R. G., 1991. The electrochemistry of SRB corrosion and related inorganic phenomena, ISIJ International, 31: 201-204.

Omorodion, K., 1988. Use of Clay in Wastewater Treatment, Unpublished B.Sc Thesis, Department of Chemistry, University of Benin, Benin City, Nigeria.

Postgate, J. R., 1979. The Sulphate Reducing Bacteria, Cambridge: Cambridge University Press.

Pritchard, A. M., 2002. Biocorrosion Risk Assessment, A Paper presented at European summer school on biologically influenced corrosion, University of Portsmouth, U.K.

Pryfogle, P. A., 2002. Geothermal Biocorrosion, U.S. Department of Energy Conversion Technology, Bulletin Energy, No. 317: 16-18.

Rahaman, M. A., 1976. Review of the basement geology of Southwestern Nigeria: In Geology of Nigeria, edited by Kogbe, C. A., Elizabeth Publishing Company, Lagos.

Rim-Rukeh, A. and Puyate, Y. T., 2007. Corrosion of X60 steel influenced by iron oxidizing bacteria (Leptothrix discophora), Global Journal of Engineering Research, 6(1): 51-56.

Rosser, H. R. and Hamilton, W. A., 1983. A simple assay for the accurate determination of sulphate reduction activity, Applied and Environmental Microbiology, 45: 1956-1959.

Sanders, P. F., 1983. Biological aspects of marine corrosion, Metals Society World, 7: 13-14.

Schlegel, H. G., 1993. General Microbiology, Cambridge: Cambridge University Press, UK 
Starkey, R. L. and Wight, K. M., 1983. Anaerobic corrosion of iron in soil, American Gas Association Bulletin, 17: 11-13.

Stein, A. A., 1993. MIC Treatment and Prevention: In $A$ Practical Manual on MIC, edited by Kobrin, G., NACE, Houston, Texas.

Videla, H. A., 1996. Manual of Biocorrosion, Florida: CRC Lewis Publishers. 